\title{
Enhanced Visible Light Absorption by 3C-SiC Nanoparticles Embedded in Si Solar Cells by Plasma-Enhanced Chemical Vapor Deposition
}

\author{
Bhaskar Parida, Jaeho Choi, Gyoungho Lim, Kiseok Kim, and Keunjoo Kim \\ Department of Mechanical Engineering and Research Center of Industrial Technology, \\ Chonbuk National University, Jeonju 561-756, Republic of Korea \\ Correspondence should be addressed to Keunjoo Kim; kimk@chonbuk.ac.kr
}

Received 23 July 2013; Revised 4 October 2013; Accepted 28 October 2013

Academic Editor: Takuya Tsuzuki

Copyright $\odot 2013$ Bhaskar Parida et al. This is an open access article distributed under the Creative Commons Attribution License, which permits unrestricted use, distribution, and reproduction in any medium, provided the original work is properly cited.

\begin{abstract}
Solar cells with 3C-SiC nanoparticles embedded in the Si were investigated by plasma-enhanced chemical vapor deposition. Several sizes of SiC nanoparticles were used as the intermediate layer for the solar cell. The Si thin films showed the formation of microand nanocrystallites on the $\mathrm{SiC}$ nanoparticle sites, which play an important role of heating block as a nanosubstrate. The Raman spectra revealed that the $\mathrm{SiC}$ nanoparticles were embedded in mixed phases of amorphous and nanocrystalline Si. Compared to the conventional solar cell sample, the photoreflectance was significantly reduced in the UV/visible spectral region due to the presence of the embedded 3C-SiC nanoparticles. The Si nanocrystals formed by the thin film deposition played an important role in reducing the photoreflectance within the visible to infrared spectral zones. Furthermore, the SiC nanoparticles contributed less in the photoabsorption at a longer infrared spectral zone wavelength of $1200 \mathrm{~nm}$.
\end{abstract}

\section{Introduction}

In recent years, several nanostructures, such as nanowires, quantum dots, photonic crystals, and ultra-small nanoparticles, have been widely investigated to improve the efficiency of Si solar cells [1-4]. These ultra-small nanoparticles used in Si solar cells enhance the light coupling in the ultraviolet (UV)/visible spectral range to increase the radiative recombination of photoexcited excitons and carrier transportation and produce a high voltage with improved power performance [5]. Si solar cells have very low UV spectral response due to low band gap energy $\left(E_{g}=1.12 \mathrm{eV}\right)$, which is a major limitation for collecting photogenerated carriers across $\mathrm{Si}$ to generate electrical energy from the UV spectra. To overcome such limitation, nanocrystals have been hybridized on Si solar cells to achieve a twofold enhancement in the cell efficiency under UV light, and wide band gap materials have been used [6].

Silicon carbide $(\mathrm{SiC})$ is an indirect and wide band gap $\left(E_{g}=2.3 \mathrm{eV}\right)$ semiconductor with quite good electrical properties such as high electron mobility and saturation drift velocity. $\mathrm{SiC}$ is widely used in photonics and optoelectronics $[7,8]$. $\mathrm{SiC} / \mathrm{TiO}_{2}$ nanocomposites can be used as a photoelectrode that produces high power conversion efficiency in dyesensitized solar cells [9]. SiC used as a window layer in a homojunction photodiode enhances the quantum efficiency with increased photo response in the shorter wavelength spectral region [10]. Furthermore, colloidal SiC nanocrystals absorb light in the UV/visible spectral range [11] and act as an antireflection coating on the Si solar cell [12]. Therefore, it is of interest to use $\mathrm{SiC}$ nanoparticles on $\mathrm{Si}$ solar cells to increase the photo response in the shorter wavelength in order to enhance photocurrent generation.

In this work, $\mathrm{Si}$ solar cells were investigated using 3C$\mathrm{SiC}$ nanoparticles as an intermediate layer. Ultra-small $\mathrm{SiC}$ nanoparticles were fabricated by an anisotropic wet chemical etching process using $50 \mathrm{~nm} \mathrm{SiC} \mathrm{nanoparticles.} \mathrm{In} \mathrm{this} \mathrm{pro-}$ cess, $\mathrm{SiC}$ nanoparticles of 7, 10, 20, and $50 \mathrm{~nm}$ were sprayed on Si solar cells surfaces, and a $100 \mathrm{~nm}$ thick Si thin film was deposited by plasma-enhanced chemical vapor deposition (PECVD). Si nanocrystals and nanoclusters were formed by Si thin film deposition. The SiC nanoparticles showed very 
low photoreflectance $(\mathrm{PR})$ in the UV to visible spectra region depending on size. Furthermore, the deposited Si thin film containing Si nanocrystals enhanced the photo absorption in the IR spectral zone, and the SiC nanoparticles showed very high $\mathrm{PR}$ above the IR region.

\section{Experiment Details}

In the experiment, $2 \times 2 \mathrm{~cm}^{2}$, single crystalline $\mathrm{p}$ - $\mathrm{n}$ junction type microtextured $\mathrm{Si}$ solar cells were used. In order to remove the phosphosilicate glass, the samples were etched with $5 \% \mathrm{HF}$ for $30 \mathrm{sec}$, rinsed with ultra-pure deionized (DI) water for $5 \mathrm{~min}$, and dried using a $\mathrm{N}_{2}$ gun. Then, $10 \mathrm{~nm}$, $20 \mathrm{~nm}$, and $50 \mathrm{~nm}$ diameter 3C-SiC nanoparticles powders (Nanostructured \& Amorphous Materials, Inc) were mixed with $5 \mathrm{~mL}$ of ethanol to form suspensions. Furthermore, chemical etching of $\mathrm{SiC}$ nanoparticles was performed to obtain ultra-small $\mathrm{SiC}$ nanocrystals less than $10 \mathrm{~nm}$. Next, $1 \mathrm{gm}$ of $50 \mathrm{~nm} \mathrm{SiC}$ nanoparticles was etched in a $40 \% \mathrm{HF}$ and $65 \%$ nitric acid $\left(\mathrm{HNO}_{3}\right)$ solution at $100^{\circ} \mathrm{C}$ for 1 hour. After etching, the cubic $\mathrm{SiC}$ nanoparticles were repeatedly washed with DI water and dried in an oven at $70^{\circ} \mathrm{C}$ for several hours. To obtain numerous separated nanoparticles, the etched porous powder was mechanically ground with an agate mortar for $1 \mathrm{hr}$. The ground powder was then dispersed in ethanol and ultrasonicated for $30 \mathrm{~min}$. The formed suspension was centrifuged at an acceleration of $3000 \mathrm{~g}$ for $45 \mathrm{~min}$, and the top part of the suspension, which contained uniformly dispersed cubic $\mathrm{SiC}$ nanocrystals, was collected. The dispersed nanoparticles with diameters of 7, 10, 20, and $50 \mathrm{~nm}$ were sprayed over the microtextured Si solar cell samples and dried in an oven at temperature $70^{\circ} \mathrm{C}$ for $10 \mathrm{~min}$.

Next, $100 \mathrm{~nm}$ thick Si film was deposited on each $\mathrm{SiC}$ nanoparticle-coated, microtextured Si solar cell sample using a parallel plate PEVCD consisting of an ultra-high-vacuum chamber (base pressure $1 \times 10^{-9}$ Torr) and a RF generator $(13.56 \mathrm{MHz})$, connected through a matching network at the top of the reactor electrode. The bottom electrode was grounded and also acted as the substrate holder. The deposition process was performed using $60 \mathrm{~W}$ of input power. The samples were heated to $200^{\circ} \mathrm{C}$ during the deposition. The precursor gases were high purity (99.99\% or higher) $\mathrm{SiH}_{4}$ and $\mathrm{H}_{2}$ of 166 and $33 \mathrm{sccm}$, respectively. The total pressure during the deposition process was maintained at approximately 1 $\times 10^{-9}$ Torr. The deposition was performed for $166 \mathrm{sec}$. The structural, vibrational, and optical properties of the embedded $\mathrm{SiC}$ nanoparticle Si solar cell samples were characterized by a field-emission scanning electron microscope (FE-SEM), $\mathrm{X}$-ray diffraction (XRD), Raman spectroscopy, and PR measurements. Furthermore, the sizes of the $\mathrm{SiC}$ nanoparticles were measured by a transmission electron microscope (TEM).

\section{Results and Discussion}

Figure 1 shows the high resolution TEM (HR-TEM) and TEM images of the 3C-SiC nanoparticles of various sizes dispersed on a carbon-coated TEM grid where (a), (b), (c), and (d) are the $\mathrm{SiC}$ nanoparticles of diameter $7 \mathrm{~nm}, 10 \mathrm{~nm}, 20$, and $50 \mathrm{~nm}$, respectively. The colloidal nanoparticles were investigated using a FE-TEM (JEOL JEM2200FS). Figure 1(a) demonstrates that the 3C-SiC nanocrystals were nearly spherical with an average diameter of $7 \mathrm{~nm}$. However, the lattice fringes of the nanocrystals correspond to different planes that indicate that the nanocrystals are a mix of single and polycrystals. Figures 1(b) and 1(c) are the TEM images of the spherical 10 and $20 \mathrm{~nm} \mathrm{SiC} \mathrm{nanoparticles} \mathrm{that} \mathrm{are} \mathrm{randomly} \mathrm{dis-}$ tributed and slightly agglomerated. However, the $50 \mathrm{~nm} \mathrm{SiC}$ nanoparticles shown in Figure 1(d) are highly agglomerated. The selected area electron diffraction (SAED) pattern of each nanoparticle shown in the top, right corner of their corresponding images indicates that the $\mathrm{SiC}$ nanoparticles are crystalline.

Figure 2 shows the FE-SEM images of the removed saw damage flat Si solar cell samples coated with various sizes of $\mathrm{SiC}$ nanoparticles. Figure 2(a) shows the sample coated with $7 \mathrm{~nm} \mathrm{SiC}$ nanoparticles. Similarly, Figures 2(b), 2(c), and 2(d) show the FE-SEM images of the samples coated with 10, 20, and $50 \mathrm{~nm} \mathrm{SiC} \mathrm{nanoparticles,} \mathrm{respectively.} \mathrm{The} \mathrm{morphology}$ of the $\mathrm{SiC}$ nanoparticles was spherical. The nanoparticles were very agglomerated and adhered strongly to the solar cell surface. The density of the $\mathrm{SiC}$ nanoparticles varies between the samples due to nonuniform distribution during coating.

Figure 3 shows the FE-SEM images of the solar cell surface coated with 3C-SiC nanoparticles before Si deposition by PECVD. Figure 2(a) shows the surface morphology of the sample, where $7 \mathrm{~nm} \mathrm{SiC} \mathrm{nanoparticles} \mathrm{were} \mathrm{coated} \mathrm{on} \mathrm{the}$ solar cell surface. Similarly, the surface morphology of the samples coated with 10,20, and $50 \mathrm{~nm} \mathrm{SiC} \mathrm{nanoparticles} \mathrm{are}$ shown in Figures 2(b), 2(c), and 2(d), respectively. The SiC nanoparticles were spherical and adhered strongly to the solar cell surface. Furthermore, the nanoparticles were nonuniform in distribution and highly agglomerated on the surface because of the oven-drying process at $70^{\circ} \mathrm{C}$. The density of the $7 \mathrm{~nm} \mathrm{SiC} \mathrm{nanoparticles} \mathrm{was} \mathrm{low,} \mathrm{and} \mathrm{they} \mathrm{were} \mathrm{aggregated}$ on the bottom part of the microtextured pyramids of the sample, whereas the $50 \mathrm{~nm} \mathrm{SiC} \mathrm{nanoparticles} \mathrm{had} \mathrm{a} \mathrm{very} \mathrm{high}$ density compared to the other samples. Compared to the other samples, the top of the microtextured solar cell sample surface (d) was fully covered by $50 \mathrm{~nm} \mathrm{SiC} \mathrm{nanoparticles.}$

Figure 4 shows the FE-SEM images of the surface morphology of all SiC nanoparticle-embedded, microtextured $\mathrm{Si}$ solar cell samples. The SiC nanoparticles are embedded in a $100 \mathrm{~nm}$ Si thin film deposited by PECVD. Figure 4(a) shows the deposited $\mathrm{Si}$ thin film on the $7 \mathrm{~nm} \mathrm{SiC} \mathrm{nanoparticles}$ coated on the microtextured $\mathrm{Si}$ solar cell sample, illustrating tetragonal Si microcrystallites of several micrometers. Figure 4(b) shows the Si thin film deposited on the microtextured Si surface, where the $10 \mathrm{~nm} \mathrm{SiC} \mathrm{nanoparticles} \mathrm{were}$ coated on the whole surface. The deposited surface shows the nanoscale roughness covering the SiC-coated layer. Similarly, the images of Figures 4(c) and 4(d) are Si thin films deposited on the Si microtextured surfaces of samples embedded with 20 and $50 \mathrm{~nm} \mathrm{SiC} \mathrm{nanoparticles,} \mathrm{respectively,} \mathrm{which} \mathrm{exhibited}$ similar nanostructured surfaces. The inset images show the magnified nanosurface structures with protrusions on the $\mathrm{SiC}$ sprayed sites. 

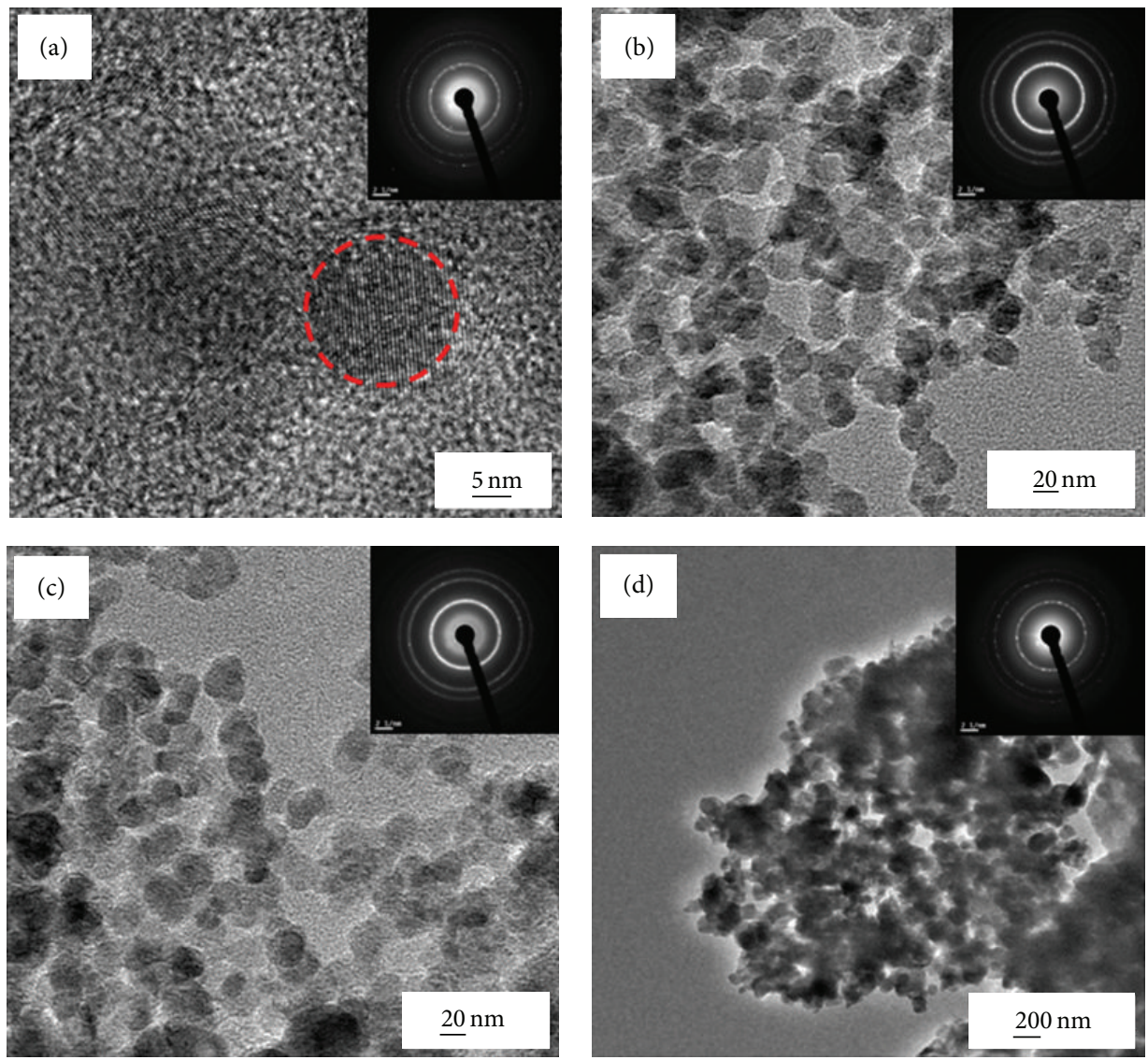

FIGURE 1: TEM images of (a) 7, (b) 10, (c) 20, and (d) $50 \mathrm{~nm}$ 3C-SiC nanoparticles dispersed on carbon-coated TEM grids with their SAED patterns. The SAED patterns indicate that the $3 \mathrm{C}-\mathrm{SiC}$ nanoparticles have a crystalline structure.
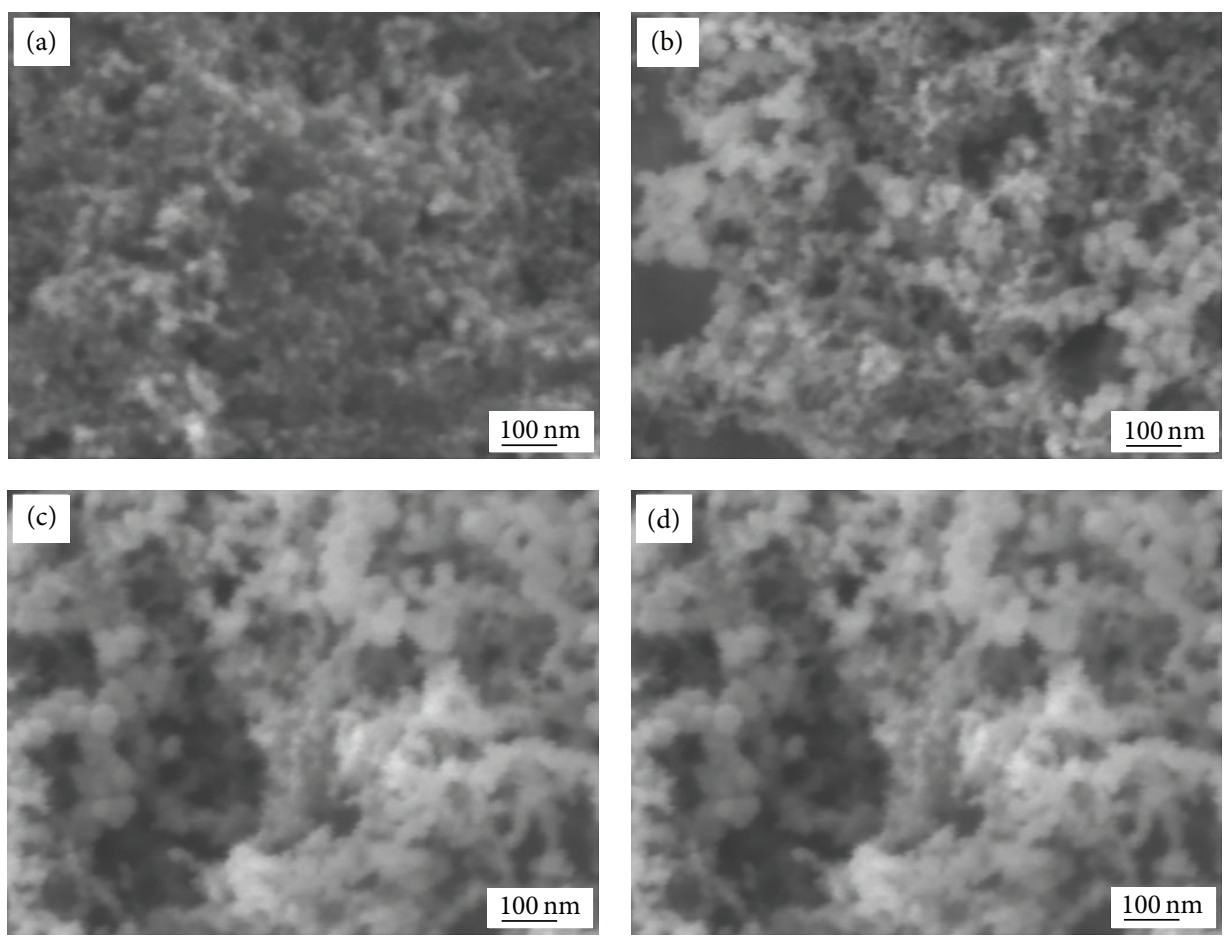

Figure 2: FE-SEM images of (a) 7, (b) 10, (c) 20, and (d) $50 \mathrm{~nm}$ 3C-SiC nanoparticles sprayed on the saw damage removed flat Si solar cell samples. The distribution of the $\mathrm{SiC}$ nanoparticles is nonuniform. 

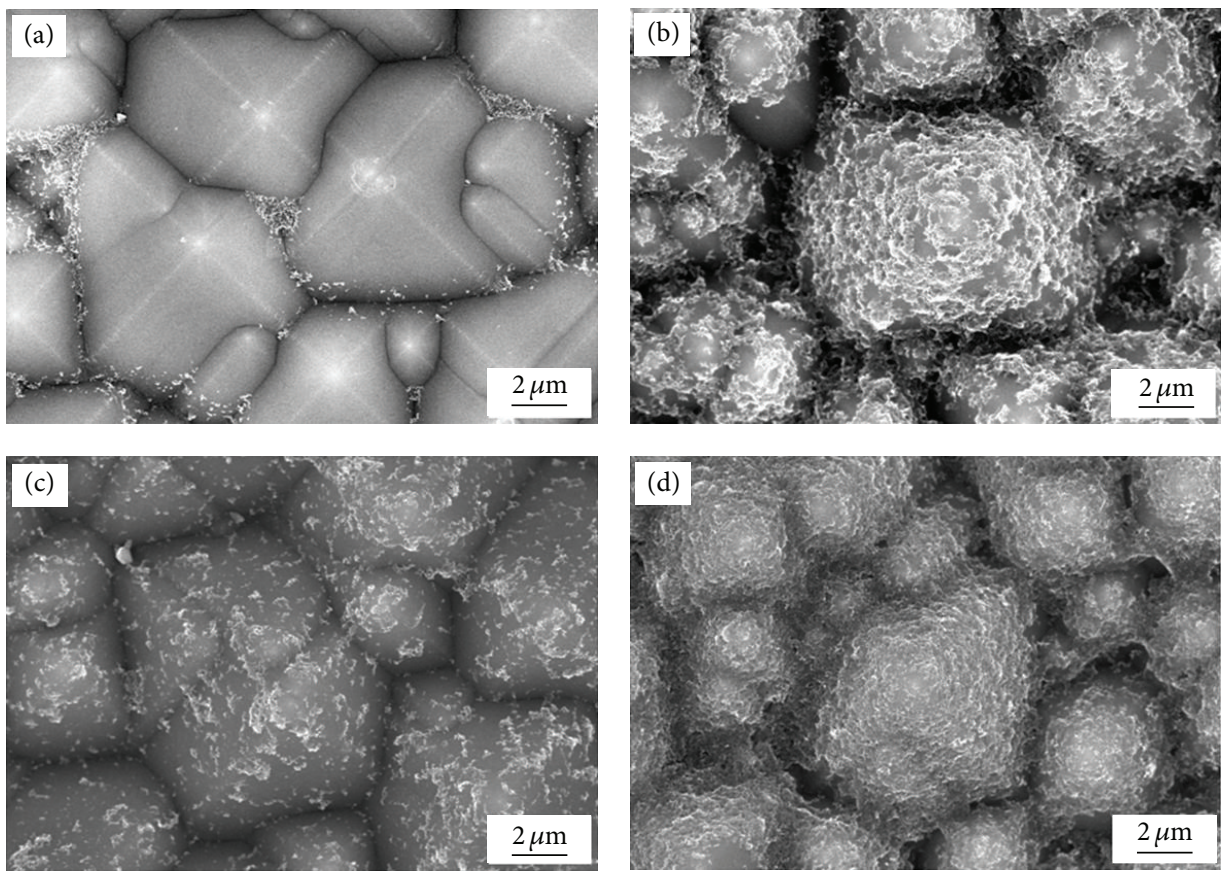

FIGURE 3: FE-SEM images of the (a) 7, (b) 10, (c) 20, and (d) $50 \mathrm{~nm}$ 3C-SiC nanoparticles sprayed on the microtextured Si solar cell samples before Si thin film deposition by PECVD. The 3C-SiC nanoparticles are randomly distributed and highly aggregated on the samples surfaces.
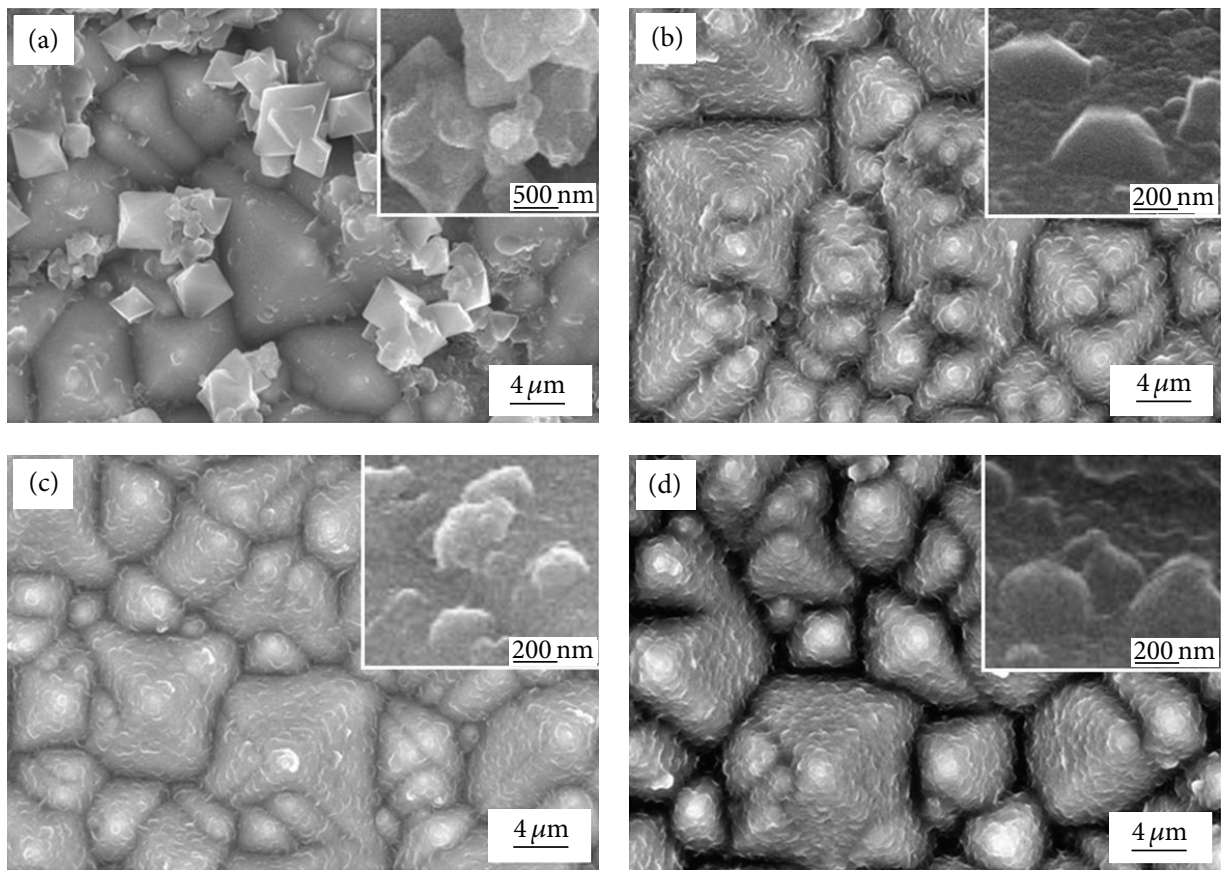

FIGURE 4: FE-SEM images of the Si solar cell samples with (a) 7, (b) 10, (c) 20, and (d) $50 \mathrm{~nm}$ SiC nanoparticles embedded in $100 \mathrm{~nm}$ thick Si thin film using PECVD. The image (a) shows the formation of tetragonal-shaped Si microcrystals on the $7 \mathrm{~nm} \mathrm{SiC-embedded} \mathrm{sample} \mathrm{surface,}$ and Si nanocrystals are observed on the 10, 20, and $50 \mathrm{~nm} \mathrm{SiC} \mathrm{nanoparticle-embedded} \mathrm{microtextured} \mathrm{Si} \mathrm{solar} \mathrm{cell} \mathrm{samples.}$

The Si thin film deposited sample on the microtextured surface coated with $7 \mathrm{~nm} \mathrm{SiC} \mathrm{nanoparticles} \mathrm{was} \mathrm{very} \mathrm{similar}$ to that observed in a previous work [13], and the formation of such types of Si microcrystals are theoretically well explained $[14,15]$. These microcrystals were formed on the $7 \mathrm{~nm} \mathrm{SiC}$ nanoparticle-embedded sample, where the $\mathrm{SiC}$ was highly agglomerated. The $\mathrm{SiC}$ nanoparticles in the sample surface peaks provide an environment in which $\mathrm{Si}$ species collected on the $\mathrm{SiC}$ sites. The Si nanocrystals are formed due to the surface energy caused by the extraction of hydrogen radicals 


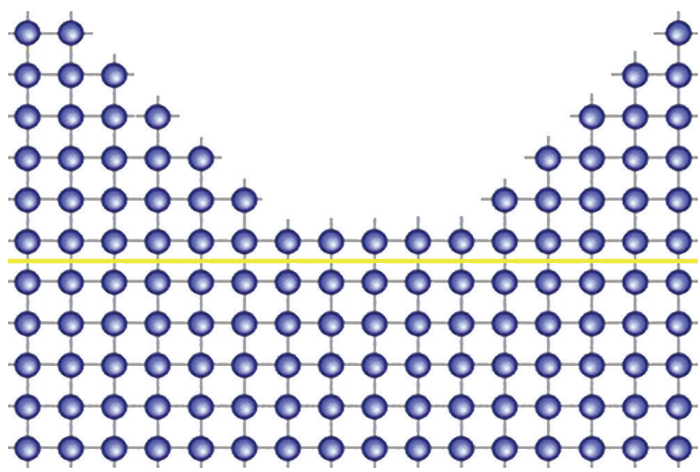

(a) Microtexturing

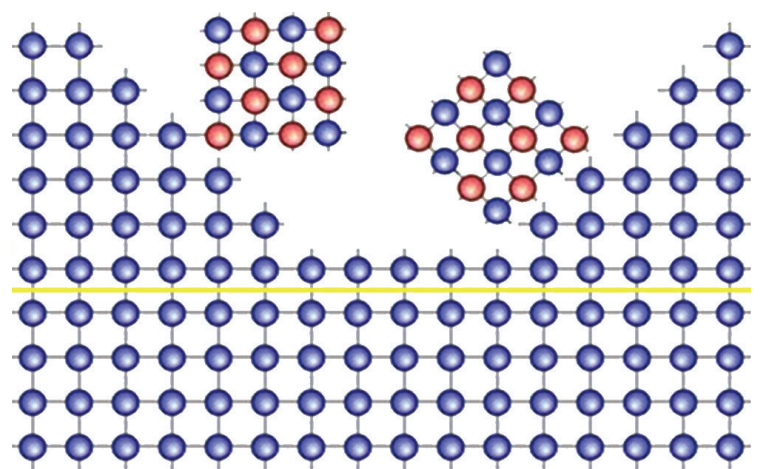

(b) $\mathrm{SiC}$ nanoparticle spraying

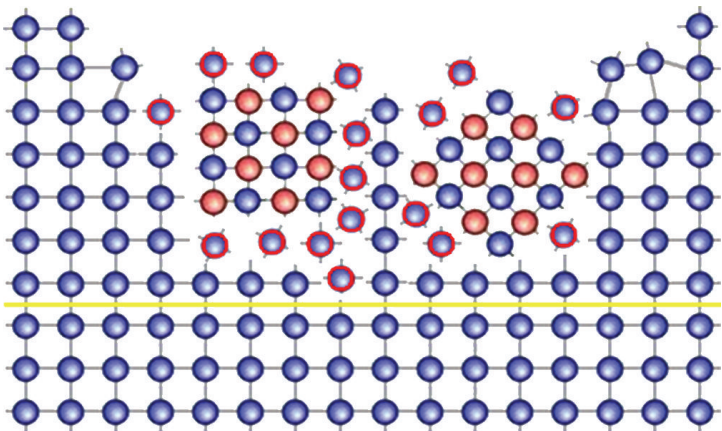

(d) Si melting on SiC nanosites

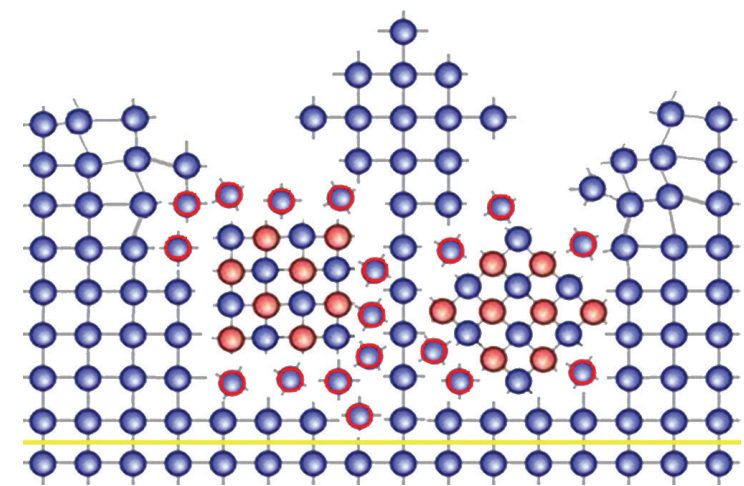

(f) Si nanocrysallite growing

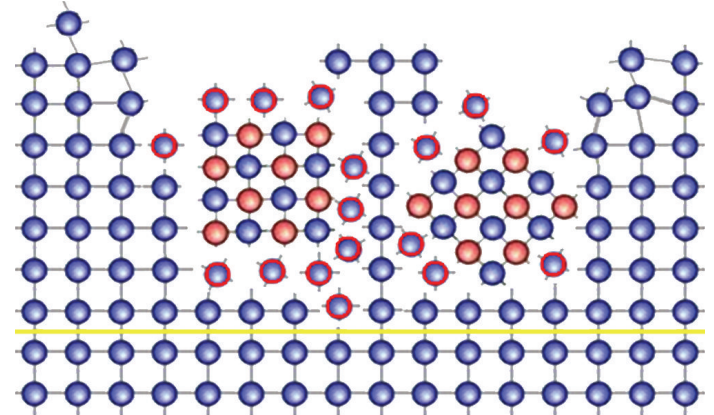

(e) Si seed nucleation

FIGURE 5: The schematic diagrams of the plasma-enhanced growth of Si nano-crystallites on the sites of SiC nanoparticle seeds from the nanofurnace mechanism for (a) the microtextured Si samples, (b) the spraying process of SiC nanoparticles, (c) Si deposition by PECVD in a mixed $\mathrm{SiH}_{4}$ and $\mathrm{H}_{2}$ gas ambient, (d) Si surface melting on the $\mathrm{SiC}$ nanoparticles, (e) Si seed nucleation, and (f) the formation of Si nanocrystallites. The plasma uniformly heats the $\mathrm{Si}$ surface, but the local $\mathrm{SiC}$ nanoparticle sites can be strongly heated by plasma absorption, resulting in interfacial melting of the Si neighbor due to nanofurnaces.

from the silicon lattice that enhanced the nucleation and formation of Si nanocrystals during the plasma treatment of PECVD $[16,17]$. According to the surface diffusion model [18], Si atoms nucleate crystallites in the early stage of deposition and diffuse for planar growth of island coalescence. For the samples with microtextured surfaces coated by 10,20 , and $50 \mathrm{~nm} \mathrm{SiC}$ nanoparticles, the $\mathrm{SiC}$ nanoparticles covered the whole surface and provided nucleation sites. The planar growth of Si thin films by the surface diffusion process covers the whole surface area. The $\mathrm{SiC}$ nanosites also show enhanced growth of nanocrystallites, as shown in the magnified images of the insets. The $\mathrm{SiC}$ thin film deposition shows the formation of Si nanocrystallites with mixed phase crystallinity [19], and the formation mechanism of the nanocrystallites on the highly heat capacitive $\mathrm{SiC}$ nanosites is believed to be a nanofurnace process.

The plasma-enhanced growth of Si nano- and microcrystallites on the sites of seeds of $\mathrm{SiC}$ nanoparticles from the nanofurnace mechanism is shown in Figure 5. The $\mathrm{SiC}$ is highly heat capacitive and can be used as a crucible material in a furnace, while the $\mathrm{SiC}$ nanoparticle acts as a heating block in the form of a nanosubstrate or a plasma-heated nanofurnace. 
Generally, when Si thin film is deposited by PECVD on a Si microtextured surface, the reference sample provides very uniform epitaxial growth of amorphous thin films. From the comparison of the SEM images of Figures 3 and 4, the morphology of Si thin film deposition is very consistent to the positions of $\mathrm{SiC}$ nanoparticles. Since the Si thin film deposition was the same for all samples, the difference in morphology corresponds to the difference in nanoparticle size. As shown in Figure 3(a), the $\mathrm{SiC}$ nanoparticles were sprayed on the valleys of the microtextured peaks of the Si surface, microcrystallites were formed on the valleys, and uniform deposition of the amorphous Si thin film was observed in the other areas. However, as shown in Figures 3(b)-3(d), the $\mathrm{SiC}$ nanoparticles were sprayed on the whole microtextured surface, and thin films grew on the areas of convex protrusions on the sites of the $\mathrm{SiC}$ nanoparticles. For the microtextured samples after spraying with $\mathrm{SiC}$ nanoparticles, the plasma of the $\mathrm{Si}$ species in $\mathrm{H}_{2}$ gas ambient heated the $\mathrm{SiC}$ nanoparticles, as in Figures 5(a)-5(c). The $\mathrm{SiC}$ nanosite as a nanofurnace can be energized by the plasma radiation, which can locally melt the Si surface and form a nucleation seed for the nanocrystallites by feeding the source of the Si plasma species, as shown in Figures 5(d)-5(f). For nanocatalytic growth of Si nanowires by the $\mathrm{Ni}$-assisted solid-liquid-solid mechanism, $\mathrm{SiC}$ nanoparticles enhance the supersaturated $\mathrm{Si}$ diffusion process and form a supersaturated Si melt [20]. Without a nanocatalyst of Ni nanoparticles, this work demonstrates the formation of micro- and nanocrystallites but not the growth of Si nanowires. Detailed analysis was performed using XRD and Raman spectroscopies.

Figure 6 shows the XRD patterns for the solar cell samples on which the 3C-SiC nanoparticles embedded in Si thin film grown by PECVD are measured using $\mathrm{CuK}_{\alpha}$ radiation. XRD analysis reveals that all samples show characteristic planes at (111), (200), (220), and (222), corresponding to the peaks centered at $2 \theta=35.05^{\circ}, 41.2^{\circ}, 58.38^{\circ}$, and $77.38^{\circ}$, respectively, of the cubic $\mathrm{SiC}$ nanoparticles previously indexed [21]. Furthermore, additional peaks of $\mathrm{Si}$ and $\mathrm{SiO}_{2}$ were observed. The broad and intense peak at $71.3^{\circ}$ is from the Si substrate, whereas the peaks with low intensity at $56.6^{\circ}$ and $71.3^{\circ}$ are from the Si thin film deposited by PECVD [22]. The peak at $49.8^{\circ}$ is from graphite [23].

The graphite peak was due to the mixture of $3 \mathrm{C}-\mathrm{SiC}$ nanoparticles. The additional peaks in the $7 \mathrm{~nm} \mathrm{SiC} \mathrm{nano-}$ particle-embedded sample indicate the presence of $\mathrm{SiO}_{2}$, although these peaks are not considered here. However, the very narrow and intense peak at the (111) plane indicates that the particle sizes increased due to a chuck temperature of $200^{\circ} \mathrm{C}$ and good crystallization. A narrow and intense peak at $2 \theta=63.71^{\circ}$ appears due to the $\mathrm{CuK}_{\alpha}$ radiation diffracted from $\mathrm{Si}$, and the broad high peak at $2 \theta=71.3^{\circ}$ appears from the single crystal Si substrate, in good agreement with a previous study [24]. Furthermore, a stacking fault did not appear at $2 \theta=33.6^{\circ}$ [25].

Figure 7 shows the room temperature Raman spectra of the solar cell samples with different size cubic $\mathrm{SiC}$ nanoparticles embedded in the Si thin film deposited by PECVD as measured by a micro-Raman spectrometer with an irradiation wavelength of $632.768 \mathrm{~nm}$. A wide and small peak

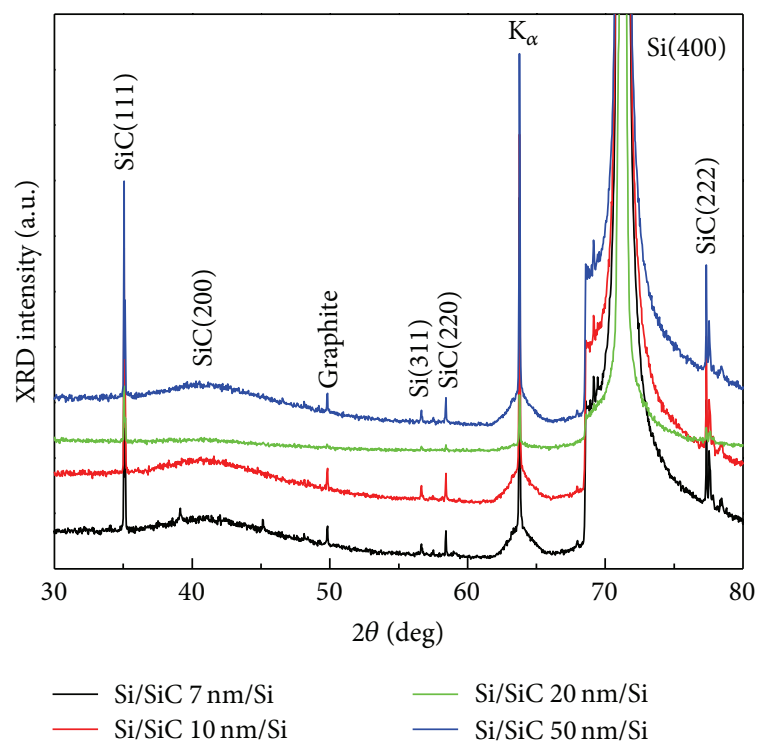

FIGURE 6: XRD spectra of the Si solar cell samples with 7, 10, 20, and $50 \mathrm{~nm} \mathrm{SiC} \mathrm{nanoparticles} \mathrm{embedded} \mathrm{in} \mathrm{Si} \mathrm{thin} \mathrm{film} \mathrm{using} \mathrm{PECVD.}$

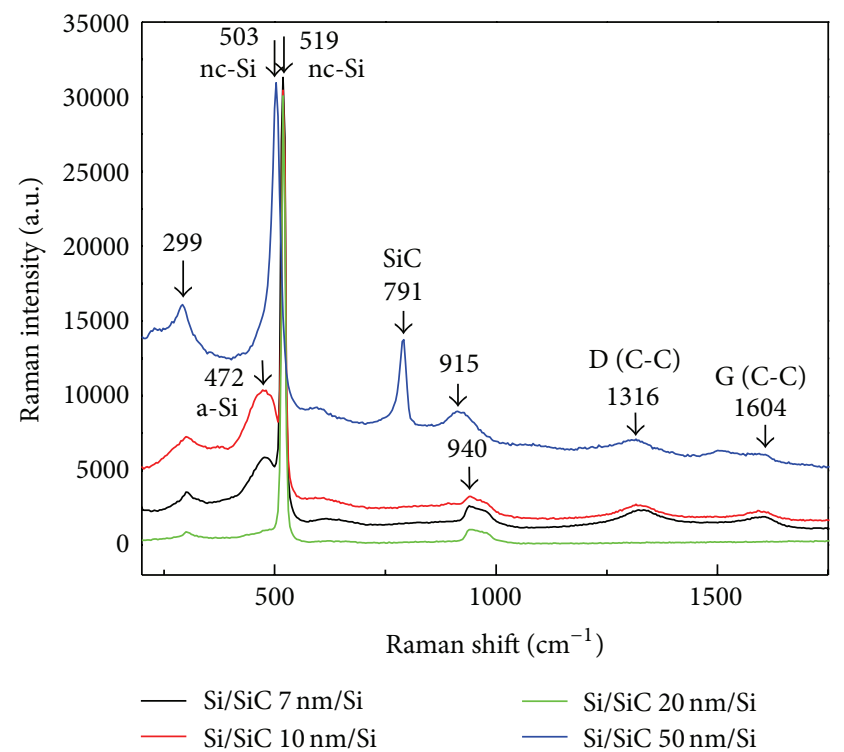

Figure 7: Raman spectra of the 3C-SiC-embedded Si solar cell samples. The $\mathrm{SiC}$ nanoparticles are embedded in the mixed phase of amorphous and nanocrystalline Si matrices.

at $299.97 \mathrm{~cm}^{-1}$ appeared due to the second-order acoustic phonon mode of bulk Si. However, the optical phonon peaks for $\mathrm{SiC}$ nanoparticles samples with 7, 10, $20 \mathrm{~nm}$ were observed at $519 \mathrm{~cm}^{-1}$, but the peak was shifted to $503.55 \mathrm{~cm}^{-1}$ for the sample with $50 \mathrm{~nm}$ nanoparticles. Generally, the Raman peaks from micro- and nanocrystalline silicon appear at approximately $490-515 \mathrm{~cm}^{-1}$ depending on crystallite size. In our case, the 7,10, and $20 \mathrm{~nm}$ embedded samples show perfect crystalline phases of $\mathrm{Si}$, while the $50 \mathrm{~nm} \mathrm{SiC-embedded} \mathrm{sam-}$ ple exhibited a nanocrystalline phase that indicates a phase decrease with increase in $\mathrm{SiC}$ nanoparticle size. Furthermore, 
the 20 and $50 \mathrm{~nm} \mathrm{SiC-embedded} \mathrm{samples} \mathrm{show} \mathrm{a} \mathrm{high} \mathrm{and}$ low amorphous tail below 503.55 and $519 \mathrm{~cm}^{-1}$, respectively, whereas the 7 and $10 \mathrm{~nm} \mathrm{SiC-embedded} \mathrm{samples} \mathrm{have} \mathrm{a}$ weaker peak at $472.6 \mathrm{~cm}^{-1}$ due to the presence of the amorphous silicon phase in the surface layer. Therefore, the 3C-SiC nanoparticles are embedded under the mixed phase of nanocrystalline and amorphous silicon.

The shifts of the phonon peaks from 519 to $503.55 \mathrm{~cm}^{-1}$ with broadening depend on the size-dependent phonon confinement effect [26]. However, a stress-free 3C-SiC single crystal has two strong transverse and longitudinal optical phonon modes (TO and LO) with Raman shifts at 796 and $972 \mathrm{~cm}^{-1}$, respectively. In our case, only the sample (d) shows a TO phonon mode whose Raman shift at $791 \mathrm{~cm}^{-1}$ indicates that the $100 \mathrm{~nm}$ thin film of Si dominates all the SiC nanoparticles, except the $50 \mathrm{~nm} \mathrm{SiC}$-embedded sample. Furthermore, the Raman peaks at 1316.22 and $1604.8 \mathrm{~cm}^{-1}$ are related to the $\mathrm{D}$ and $\mathrm{G}$ bands, respectively, of the $\mathrm{C}-\mathrm{C}$ of the graphite nanoparticles that are mixed with $3 \mathrm{C}-\mathrm{SiC}$ nanoparticles [27].

Figure 8 shows the PR spectra of the $\mathrm{SiC}$ nanoparticlecoated and embedded Si solar cell samples. Figure 8(a) shows the PR of the $\mathrm{SiC}$ nanoparticles coating the flat $\mathrm{Si}$ solar cells. The flat reference sample shows the highest PR that was greater than $30 \%$ in all wavelengths of the solar spectrum, satisfying the poor absorption property of Si due to its narrow band gap. The $50 \mathrm{~nm} \mathrm{SiC} \mathrm{nanoparticle-coated} \mathrm{flat} \mathrm{Si} \mathrm{solar} \mathrm{cell}$ shows slightly lower PR than the reference. However, the 7$20 \mathrm{~nm} \mathrm{SiC} \mathrm{nanoparticle-coated} \mathrm{flat} \mathrm{Si} \mathrm{solar} \mathrm{cells} \mathrm{show} \mathrm{approx-}$ imately $20 \%$ reduced PR in the UV/VIS wavelength of 242$472 \mathrm{~nm}$ compared to the $50 \mathrm{~nm} \mathrm{SiC}$ nanoparticle-coated sample. Figure 8(b) shows the PR of the microtextured Si solar cell samples coated with $\mathrm{SiC}$ nanoparticles. The PR of the SiC nanoparticle-coated sample is reduced to a wavelength less than $472 \mathrm{~nm}$ compared to the microtextured reference sample. As decreasing the particles size from 7 to $50 \mathrm{~nm}$, the PR intensity was gradually decreased and the PR peak was red shifted. The $50 \mathrm{~nm} \mathrm{SiC} \mathrm{nanoparticle-coated} \mathrm{sample} \mathrm{shows}$ a similar PR to the microtextured sample above the visible wavelength of $472 \mathrm{~nm}$; however, in the same region, the $\mathrm{PR}$ reduced with decreasing $\mathrm{SiC}$ nanoparticles size. The decreased $\mathrm{PR}$ in the UV/VIS region caused by the $\mathrm{SiC}$ nanoparticle-coated Si solar cell samples satisfies the sizedependent and wide band gap property of SiC.

In Figure 8(c), the microtextured references sample shows the highest PR from the UV to visible spectral region wavelengths of 200-600 nm compared to the Si thin film deposited over the $\mathrm{SiC}$ nanoparticle-coated solar cell samples. The $20 \mathrm{~nm}$ SiC nanoparticle-embedded sample shows greater photoabsorption in the UV and visible region with wavelengths of 233 and $518 \mathrm{~nm}$, respectively, and a high PR in the visible spectra region with a wavelength $668 \mathrm{~nm}$. High photoabsorption and low PR in the UV spectral region with wavelengths of 236 and $272 \mathrm{~nm}$, respectively, were observed for the embedded $7 \mathrm{~nm} \mathrm{SiC} \mathrm{nanoparticles} \mathrm{but} \mathrm{not}$ for the $10 \mathrm{~nm}$ or $50 \mathrm{~nm} \mathrm{SiC} \mathrm{nanoparticle-embedded} \mathrm{samples.}$ Furthermore, the $10 \mathrm{~nm} \mathrm{SiC} \mathrm{nanoparticle-embedded} \mathrm{sample}$ shows higher photoabsorption in the UV to visible spectra region at wavelengths of $340-490 \mathrm{~nm}$ and the visible region at a wavelength of $541 \mathrm{~nm}$ to the IR region with a wavelength of $1015 \mathrm{~nm}$. The $50 \mathrm{~nm} \mathrm{SiC-embedded} \mathrm{sample} \mathrm{shows} \mathrm{low} \mathrm{PR}$ in the IR region compared to the sample embedded with 7 and $20 \mathrm{~nm} \mathrm{SiC}$. However, the reference sample shows the lowest PR at the longer IR spectral region. Among the SiCembedded samples, the sample embedded with $50 \mathrm{~nm} \mathrm{SiC}$ nanoparticles showed the lowest PR, indicating that smaller $\mathrm{SiC}$ nanoparticles have less contribution in the IR region above $1200 \mathrm{~nm}$.

The red shift in PR with increasing the size from 7 to $50 \mathrm{~nm}$ is similar to the optical absorption in metal nanoparticles [28]. However, for the photoluminescence of $\mathrm{SiC}$ nanoparticles, the blue shift of light emission happens as decreasing the size of nanoparticles with $3-5 \mathrm{~nm}$ indicating the quantum size effect [29]. All samples show significant light absorption in the IR region at the wavelength of $1015 \mathrm{~nm}$ compared to the UV and visible region, which is related to the band gap property of Si. The very low $\mathrm{PR}$ from the visible to IR region with wavelengths of $540-1015 \mathrm{~nm}$ from the $7 \mathrm{~nm} \mathrm{SiC}$ nanoparticle-embedded sample may occur due to the formed $\mathrm{Si}$ nanocrystals surrounded by $\mathrm{SiC}$ nanoparticles. However, in the same region, the sample embedded with $50 \mathrm{~nm} \mathrm{SiC}$ nanoparticles shows a lower PR than the 7 and $20 \mathrm{~nm} \mathrm{SiC}$ embedded samples because of the mixed Si nanocrystals and nanoclusters. However, the $20 \mathrm{~nm} \mathrm{SiC} \mathrm{nanoparticle-}$ embedded sample shows the highest PR above the $668 \mathrm{~nm}$ wavelength compared to all of the samples, including the reference, which may be due to the silicon nanoclusters [30]. However, the sample embedded with $7 \mathrm{~nm} \mathrm{SiC}$ nanoparticles shows a lower PR than the $20 \mathrm{~nm} \mathrm{SiC-embedded} \mathrm{sample}$ at wavelengths of $603-751 \mathrm{~nm}$, which indicates that the $\mathrm{Si}$ microcrystals absorb light better than the Si nanoclusters in that region.

The photoabsorption in the higher UV region depends on the 7, 10, and $50 \mathrm{~nm} \mathrm{SiC} \mathrm{nanoparticles;} \mathrm{however,} \mathrm{the} \mathrm{sample}$ embedded with $20 \mathrm{~nm} \mathrm{SiC}$ nanoparticles shows the greatest photoabsorption in the UV spectral region. The aberrant behaviour may be correlated with the thin film property shown in the Raman analysis, where the sample with the $20 \mathrm{~nm} \mathrm{SiC}$ nanoparticles provides a highly crystalline phase without an amorphous phase, as shown in Figure 7. In comparison, the PR was reduced by $30 \%$ for the microtextured sample compared to the flat sample; however, the PR is more reduced in the UV/Vis wavelength than that of the reference sample for both cases. Therefore, the $\mathrm{SiC}$ nanoparticles play an important role in photoabsorption from the UV to visible spectral region compared to the conventional microtextured Si solar cell sample and are related to the spectral dependence on PR and the deposited Si thin film with Si nanocrystals that enhanced the photoabsorption in the IR region. Furthermore, in the same wavelength region, the $\mathrm{PR}$ of the $\mathrm{Si} / \mathrm{SiC} / \mathrm{Si}$ solar cell samples was reduced by more than $10 \%$ compared to that of only the $\mathrm{SiC} / \mathrm{Si}$ cells, which may have occurred due to the Si nanocrystals [31]. The PR in the UV spectral region is governed by the size of the nanoparticles; that is, the PR increased with an increase in nanoparticle size [32]. The performance of the solar cells can be improved by these SiC nanoparticles with enhanced photoelectron generation due 

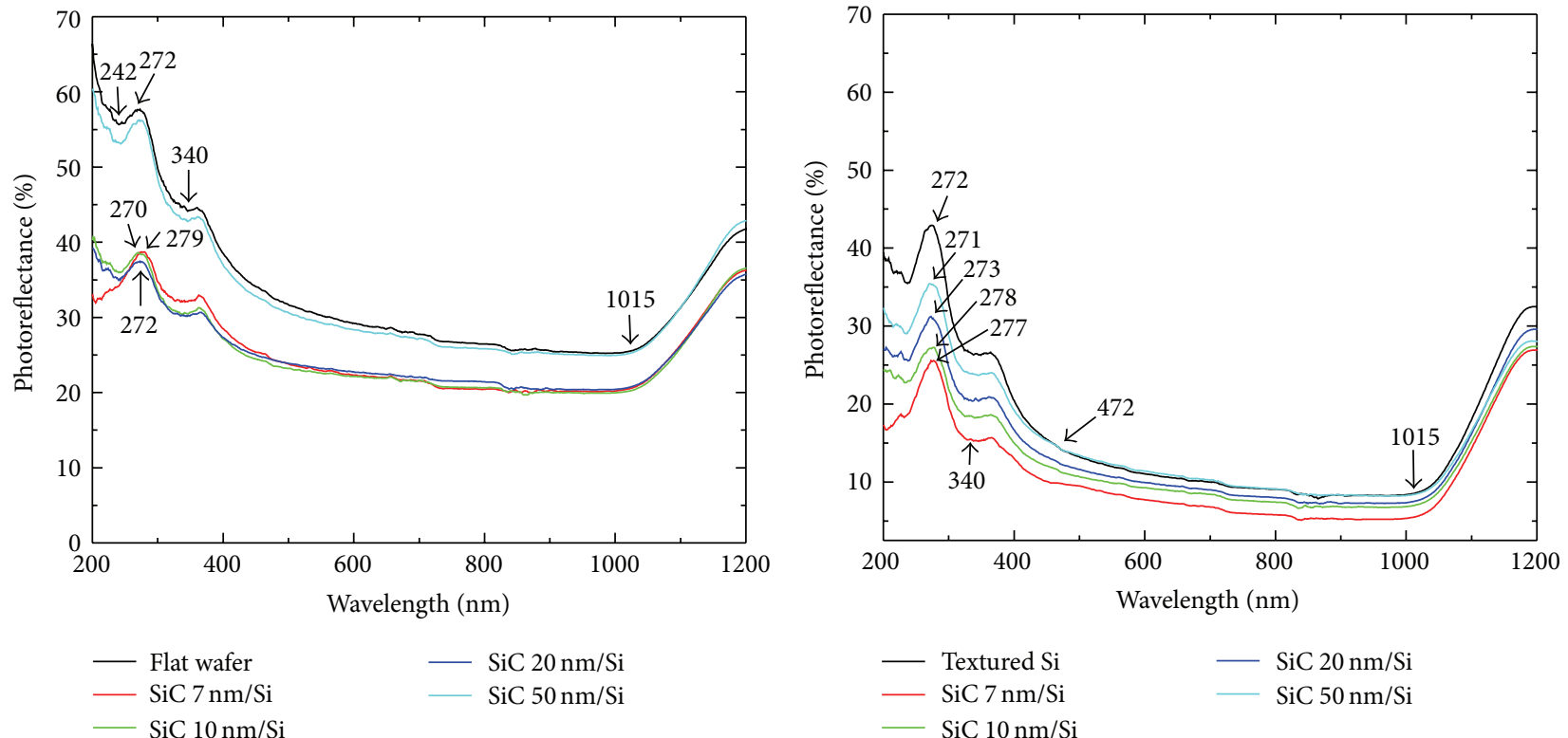

$-\mathrm{SiC} 7 \mathrm{~nm} / \mathrm{Si}$

$\mathrm{SiC} 10 \mathrm{~nm} / \mathrm{Si}$

(a)

(b)

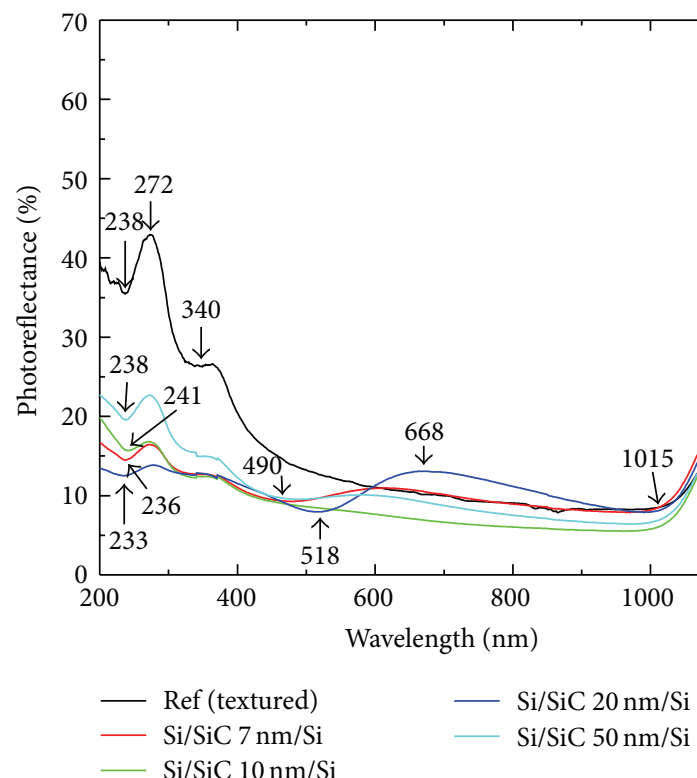

(c)

Figure 8: Photoreflectance of the Si solar cell samples coated and embedded with 7, 10, 20, and $50 \mathrm{~nm} \mathrm{SiC} \mathrm{nanoparticles.} \mathrm{The} \mathrm{PR} \mathrm{of} \mathrm{the} \mathrm{(a)} \mathrm{flat}$ and (b) microtextured Si solar cells coated with 7-50 nm SiC nanoparticles, and (c) the microtextured Si solar cell where SiC nanoparticles are embedded in the Si thin film. The photoreflectance in the UV region greatly depends on the size of the SiC nanoparticles, with the exception of the $20 \mathrm{~nm}$ nanoparticles, and the photoreflectance in the IR region is reduced by the Si nanocrystals formed in the thin film deposition.

to their high permittivity and low dissipation energy level [33].

\section{Conclusion}

Various 3C-SiC nanoparticles sizes were sprayed onto $\mathrm{Si}$ solar cells surfaces and were embedded in Si thin film by PECVD. The deposited Si thin films showed the formation of microand nanocrystallites on the $\mathrm{SiC}$ nanoparticle sites, which play an important role of a heating block in the form of a nanosubstrate or a plasma-heated nanofurnace. The surface structure of all samples depends on the density of the corresponding $\mathrm{SiC}$ nanoparticles, and the thin films showed a mixed phase of amorphous and nanocrystalline $\mathrm{Si}$ in the Raman spectra. The nanoparticles showed reduced photoreflectance in the UV spectral region. The lowest PR was observed for the sample with the $20 \mathrm{~nm} \mathrm{SiC} \mathrm{nanoparticles,} \mathrm{which} \mathrm{corresponds} \mathrm{to}$ only the nanocrystalline peak without the amorphous phase. 
The Si thin film samples showed very high PRs in the IR region. Therefore, the size-dependent $3 \mathrm{C}-\mathrm{SiC}$ nanoparticles played an important role in photoabsorption in the UV to visible spectral regions.

\section{Conflict of Interests}

The authors declare that there is no conflict of interests regarding the publication of this paper.

\section{Acknowledgment}

This research was supported by the Basic Science Research Program through the National Research Foundation of Korea (NRF) funded by the Ministry of Education, Science and Technology (NRF (2010-0025598)).

\section{References}

[1] M. L. Zhang, I. Mahmood, X. Fan, G. Xu, and N. B. Wong, "Large-area silicon nanowires from silicon monoxide for solar cell applications," Journal of Nanoscience and Nanotechnology, vol. 10, no. 12, pp. 8271-8277, 2010.

[2] A. Alguno, N. Usami, T. Ujihara et al., "Enhanced quantum efficiency of solar cells with self-assembled Ge dots stacked in multilayer structure," Applied Physics Letters, vol. 83, no. 6, pp. 1258-1260, 2003.

[3] J. Choi, B. Parida, J. T. Lee, and K. Kim, "Nanopatterned silicon emitters of a solar cell fabricated by anodic aluminum oxide masks," Journal of Nanoscience and Nanotechnology, vol. 11, no. 7, pp. 6318-6322, 2011.

[4] J. Choi, B. Parida, H. Y. Ji, S. Park, and K. Kim, "Inclusion of CdSe quantum dots on the P-doped emitter of Si solar cells," Journal of Nanoscience and Nanotechnology, vol. 12, no. 7, pp. 5619-5624, 2012.

[5] M. Stupca, M. Alsalhi, T. Al Saud, A. Almuhanna, and M. H. Nayfeh, "Enhancement of polycrystalline silicon solar cells using ultrathin films of silicon nanoparticle," Applied Physics Letters, vol. 91, no. 6, Article ID 063107, 2007.

[6] E. Mutlugun, I. M. Soganci, and H. V. Demir, "Photovoltaic nanocrystal scintillators hybridized on $\mathrm{Si}$ solar cells for enhanced conversion efficiency in UV," Optics Express, vol. 16, no. 6, pp. 3537-3545, 2008.

[7] S. Yamada, B. S. Song, T. Asano, and S. Noda, "Silicon carbidebased photonic crystal nanocavities for ultra-broadband operation from infrared to visible wavelengths," Applied Physics Letters, vol. 99, no. 20, Article ID 201102, 2011.

[8] Y. M. Liu and P. R. Prucnal, "Low-loss silicon carbide optical waveguides for silicon-based optoelectronic devices," IEEE Photonics Technology Letters, vol. 5, no. 6, pp. 704-707, 1993.

[9] Y. C. Lai and Y. C. Tsai, "An efficient 3C-silicon carbide/titania nanocomposite photoelectrode for dye-sensitized solar cell," Chemical Communications, vol. 48, no. 53, pp. 6696-6698, 2012.

[10] Y. Hirabayashi, S. Karasawa, K. Kobayashi, S. Misawa, and S. Yoshida, "Spectral response of a photodiode using 3C-SiC single crystalline film," Sensors and Actuators A, vol. 43, no. 1-3, pp. 164-169, 1994.

[11] Y. Li, C. Chen, J. T. Li, Y. Yang, and Z. M. Lin, "Surface charges and optical characteristic of colloidal cubic SiC nanocrystals," Nanoscale Research Letters, vol. 6, no. 1, article 454, 2011.
[12] N. I. Klyui, V. G. Litovchenko, V. P. Kostylyov et al., "Silicon solar cells with antireflecting and protective coatings based on diamond-like carbon and silicon carbide films," OptoElectronics Review, vol. 8, no. 4, pp. 406-409, 2000.

[13] C. Lu, W. Huang, Y. Ni, and Z. Xu, "Hydrothermal synthesis and luminescence properties of octahedral $\mathrm{LiYbF}_{4}$ : $\mathrm{Er}^{3+}$ microcrystals," Materials Research Bulletin, vol. 46, no. 2, pp. 216-221, 2011.

[14] K. Raghavachari and C. M. M. Rohlfing, "Bonding and stabilities of small silicon clusters: a theoretical study of Si7-Si10," Journal of Chemical Physics, vol. 89, no. 4, pp. 2219-2234, 1988.

[15] E. C. Honea, A. Ogura, D. R. Peale et al., "Structures and coalescence behavior of size-selected silicon nanoclusters studied by surface-plasmon-polariton enhanced Raman spectroscopy," Journal of Chemical Physics, vol. 110, no. 24, pp. 12161-12172, 1999.

[16] P. Hashemi, Y. Abdi, S. Mohajerzadeh et al., "Hydrogenationassisted nanocrystallization of amorphous silicon by radiofrequency plasma-enhanced chemical vapor deposition," Journal of Applied Physics, vol. 100, no. 10, Article ID 104320, 2006.

[17] K. Pangal, J. C. Sturm, S. Wagner, and T. H. Büyüklimanli, "Hydrogen plasma enhanced crystallization of hydrogenated amorphous silicon films," Journal of Applied Physics, vol. 85, no. 3, pp. 1900-1906, 1999.

[18] A. Matsuda, "Growth mechanism of microcrystalline silicon obtained from reactive plasmas," Thin Solid Films, vol. 337, no. 1-2, pp. 1-6, 1999.

[19] T. Y. Kim, C. Huh, N. M. Park, C. J. Choi, and M. Suemitsu, "In situ-grown hexagonal silicon nanocrystals in silicon carbidebased films," Nanoscale Research Letters, vol. 7, article 634, 2012.

[20] B. Parida, J. Choi, H. Y. Ji, S. Park, G. Lim, and K. Kim, "Nanocatalytic growth of Si nanowires from Ni silicate coated $\mathrm{SiC}$ nanoparticles on Si solar cell," Journal of Nanoscience and Nanotechnology, vol. 13, no. 9, pp. 6189-6195, 2013.

[21] Powder Diffraction Data, "JCPDS\# 29-1129, joint committee on powder diffraction standards," Associateship at the National Bureau of Standards, Swarthmore, Pa, USA, 1976.

[22] Powder Diffraction Data, "JCPDS\#27-1402, joint committee on powder diffraction standards," Associateship at the National Bureau of Standards, Swarthmore, Pa, USA, 1976.

[23] Powder Diffraction Data, "JCPDS\#41-1487, joint committee on powder diffraction standards," Associateship at the National Bureau of Standards, Swarthmore, Pa, USA, 1976.

[24] A. Gupta, D. Paramanik, S. Varma, and C. Jacob, "CVD growth and characterization of $3 \mathrm{C}-\mathrm{SiC}$ thin films," Bulletin of Materials Science, vol. 27, no. 5, pp. 445-451, 2004.

[25] L. G. Zhang, W. Y. Yang, H. Jin et al., "Ultraviolet photoluminescence from 3C-SiC nanorods," Applied Physics Letters, vol. 89, no. 14, Article ID 143101, 2006.

[26] V. Paillard, P. Puech, M. A. Laguna, R. Carles, B. Kohn, and F. Huisken, "Improved one-phonon confinement model for an accurate size determination of silicon nanocrystals," Journal of Applied Physics, vol. 86, no. 4, pp. 1921-1924, 1999.

[27] J. Jeong, G. S. Chung, and S. Nishino, "Raman scattering investigation of polycrystalline 3C-SiC film deposited on $\mathrm{SiO}_{2}$ by using APCVD with hexamethyldisilane," Journal of the Korean Physical Society, vol. 52, no. 1, pp. 43-47, 2008.

[28] U. Kreibig and L. Genzel, "Optical absorption of small metallic particles," Surface Science, vol. 156, no. 2, pp. 678-700, 1985.

[29] J. Y. Fan, X. L. Wu, H. X. Li, H. W. Liu, G. G. Siu, and P. K. Chu, "Luminescence from colloidal 3C-SiC nanocrystals in different solvents," Applied Physics Letters, vol. 88, no. 4, Article ID 041909, 2006. 
[30] A. Puzder, A. J. Williamson, J. C. Grossman, and G. Galli, "Surface control of optical properties in silicon nanoclusters," Journal of Chemical Physics, vol. 117, no. 14, pp. 6721-6729, 2002.

[31] V. Švrček, A. Slaoui, and J. C. Muller, "Silicon nanocrystals as light converter for solar cells," Thin Solid Films, vol. 451-452, pp. 384-388, 2004.

[32] N. A. Hamizi and M. R. Johan, "Synthesis and size dependent optical studies in CdSe quantum dots via inverse micelle technique," Materials Chemistry and Physics, vol. 124, no. 1, pp. 395-398, 2010.

[33] Y. A. Akimov, W. S. Koh, S. Y. Sian, and S. Ren, "Nanoparticleenhanced thin film solar cells: metallic or dielectric nanoparticles?” Applied Physics Letters, vol. 96, no. 7, Article ID 073111, 2010. 

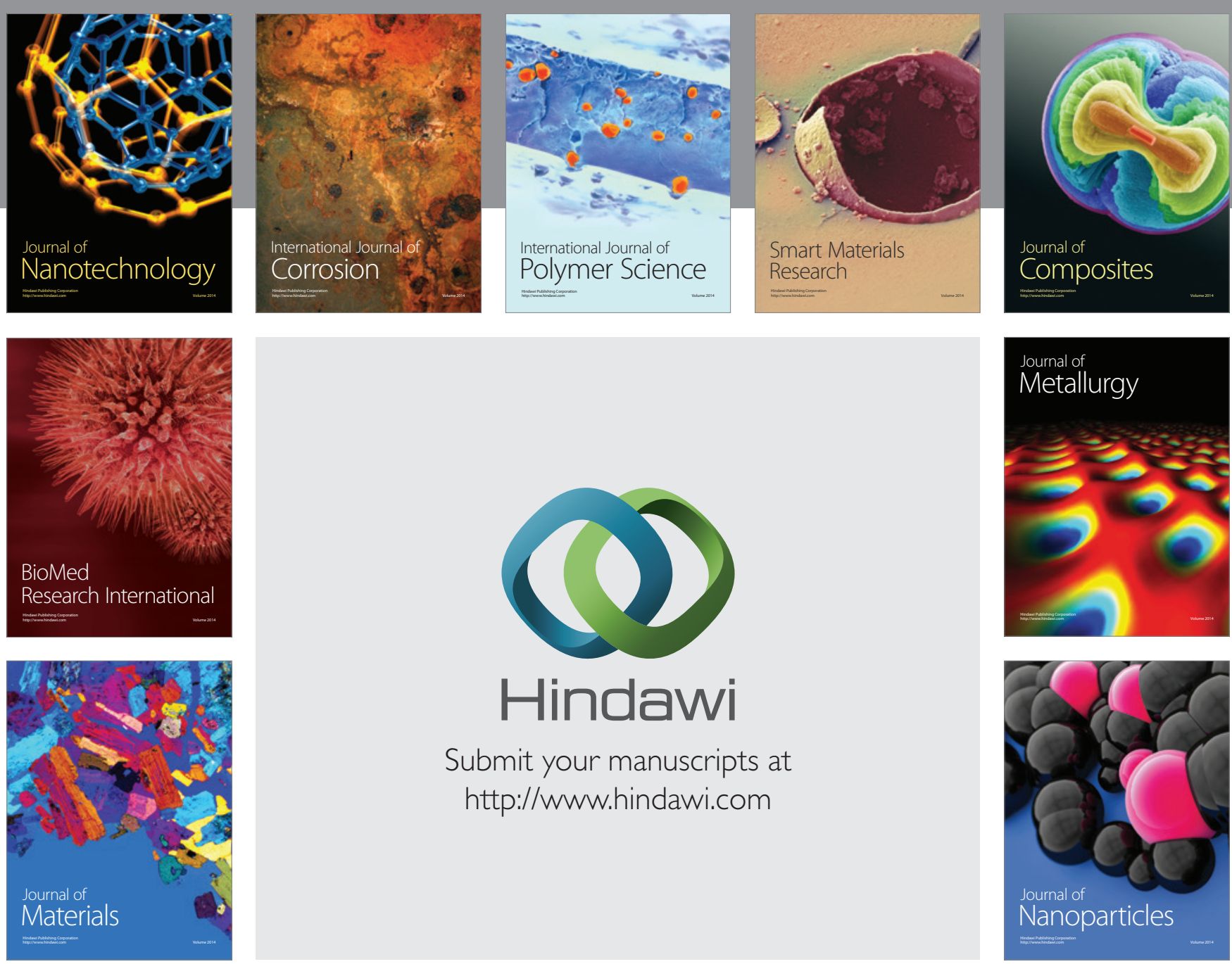

Submit your manuscripts at http://www.hindawi.com
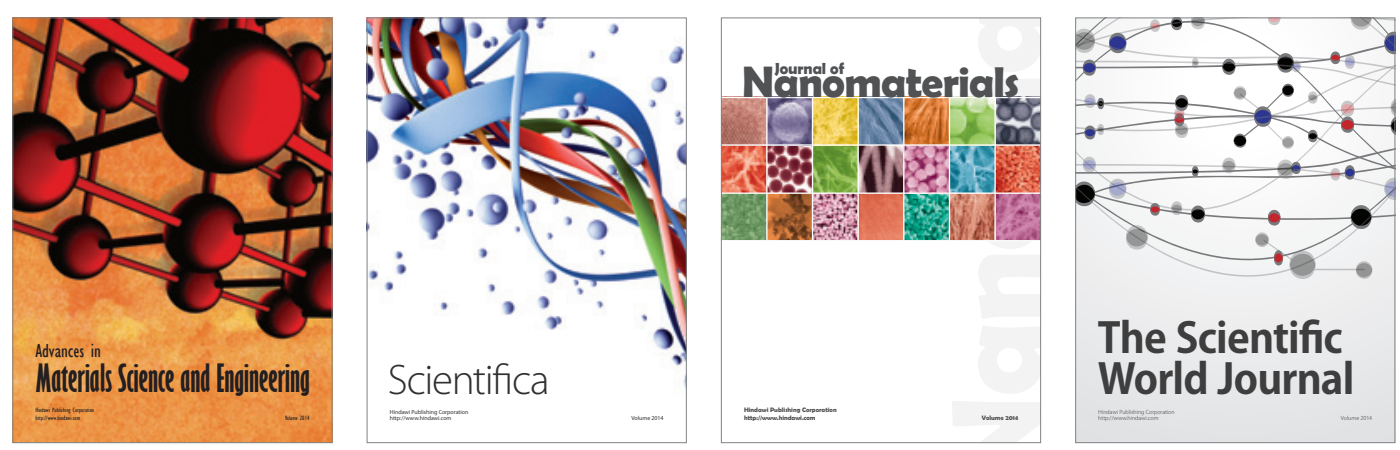

\section{The Scientific World Journal}
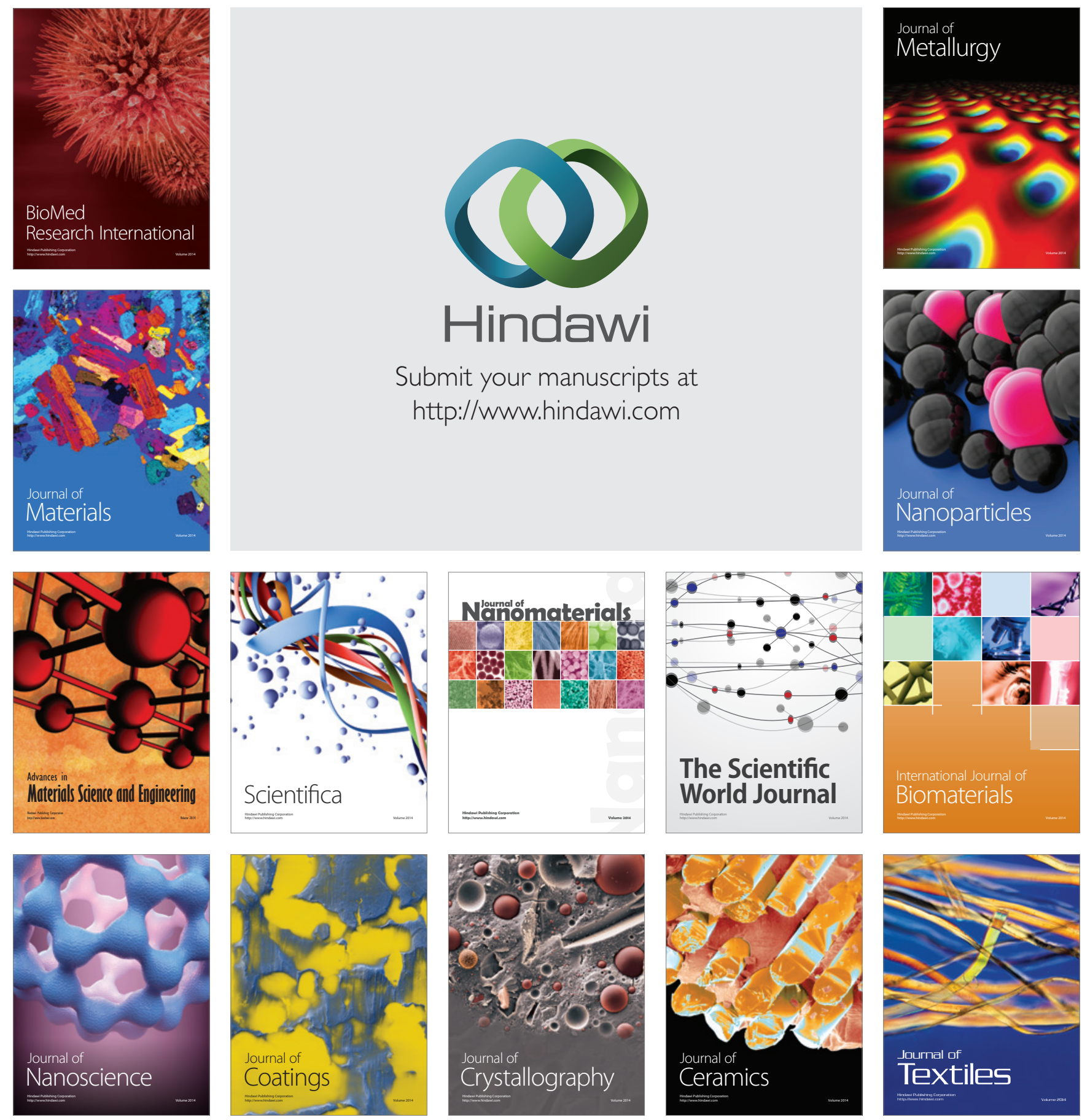